\title{
Needed communication skills during initial employment as perceived by graduates of the West Virginia University Davis College of Agriculture, Forestry and Consumer Sciences
}

Jessica R. Rollins

West Virginia University

Follow this and additional works at: https://researchrepository.wvu.edu/etd

\section{Recommended Citation}

Rollins, Jessica R., "Needed communication skills during initial employment as perceived by graduates of the West Virginia University Davis College of Agriculture, Forestry and Consumer Sciences" (2004). Graduate Theses, Dissertations, and Problem Reports. 2046.

https://researchrepository.wvu.edu/etd/2046

This Thesis is protected by copyright and/or related rights. It has been brought to you by the The Research Repository @ WVU with permission from the rights-holder(s). You are free to use this Thesis in any way that is permitted by the copyright and related rights legislation that applies to your use. For other uses you must obtain permission from the rights-holder(s) directly, unless additional rights are indicated by a Creative Commons license in the record and/ or on the work itself. This Thesis has been accepted for inclusion in WVU Graduate Theses, Dissertations, and Problem Reports collection by an authorized administrator of The Research Repository @ WVU. For more information, please contact researchrepository@mail.wvu.edu. 
Needed Communication Skills During Initial Employment as Perceived by Graduates of the West Virginia University Davis College of Agriculture, Forestry and Consumer Sciences

Jessica R. Rollins

Thesis submitted to the Davis College of Agriculture, Forestry and Consumer Science at West Virginia University in partial fulfillment of the requirements

for the degree of

Master of Science

in

Agricultural \& Environmental Education

Stacy A. Gartin, Ph.D., Chair

Harry N. Boone, Jr., Ph.D.

Deborah A. Boone, Ph.D.

Division of Resource Management

Morgantown, West Virginia 2004

Keywords: Agriculture communications, initial employment, agricultural education 


\begin{abstract}
Needed Communication Skills During Initial Employment as Perceived by Graduates of the West Virginia University Davis College of Agriculture, Forestry and Consumer Sciences
\end{abstract}

\title{
Jessica R. Rollins
}

The purpose of the study was to determine communication skills used during initial employment by graduates of the Davis College of Agriculture, Forestry and Consumer Sciences who were enrolled in the agricultural and natural resources communications (AgEE 421) course. The population consisted of 70 2001-2002 graduates of West Virginia University Davis College of Agriculture, Forestry and Consumer Sciences who were enrolled in agricultural and natural resources communications (AgEE 421) during their collegiate careers. A descriptive research design was used for the study. A major finding of the study was the beneficial effects of educational training in communications skills prior to initial employment. During initial employment, communications skills taught in AgEE 421 were frequently being actively applied. The use of these communications skills and additional findings support the continuation and expansion of agricultural communications programs. 


\section{DEDICATION}

Dedicated to my family and to all my friends:

For all the times I couldn't or I didn't, now I finally hope I have something to show for it. 


\section{ACKNOWLEDGMENTS}

To the graduates of the Davis College of Agriculture, Forestry and Consumer Sciences who were giving of their time and thoughts which allowed for the completion of this project, I extend sincere appreciation for making this possible.

To my committee as a whole, though there have been many unpredicted issues that have arose during the course of this research effort this is one hurdle we all crossed together and there is no other group of professionals I would want to collaborate with.

To Dr. Stacy A. Gartin, the numerous opportunities you have afforded me during our time together have changed my life indefinitely. You are the truest definition of an educator, not only in the classroom but also in the school of life and the impact you have is immeasurable. There simply are no words that can express my overwhelming gratitude for your support, guidance and friendship. From you I have learned the joy of being a teacher. There are few people who are so giving of themselves and who inspire others to excel, that is why I am a better person for having known you.

To Dr. Harry Boone, I am forever grateful for your generosity and willingness to help your students. Your ability to teach the most complex of ideas with a calm nature and ease is an unmatchable talent that made my graduate career much more bearable. For accepting every unscheduled interruption and donating your professionalism to this project, your contributions are numerous and greatly appreciated.

To Dr. Deborah Boone, for the work and support you have contributed to this project, I am indebted to you. Your addition to the department has completed a group of educators who are truly dedicated to the art of improvement and excellence. Thank you 
for taking the time to get to know me, and in turn helping me complete my thesis. Your efforts are remarkable.

To my family, my expression of gratitude for all that you do for me cannot be measured by words when a simple "thank you" is all I can offer. I look to you when I cannot do this on my own, and often you have believed in me when I did not believe in myself. I have learned life's tough lessons, thank you for standing back and allowing me to do so. I am blessed for having a family who are my best friends and confidants, you are a huge part of who I am today. Dan, thank you for interjecting sanity and simplicity into my life when I lost track of doing so myself and for often knowing but not saying, you have been my stable.

To my friends, I am truly blessed to have such a wonderful group of friends that I consider family. I would like to thank each of you from the bottom of my heart for always being the support and strength I need. I rest assured knowing there are people in the world that care for me the way that you all do. Thank you for listening, advising, and keeping a smile on my face, I can never repay you.

The list of people who have played a role in my life, no matter how large or small, is extensive but I would like to thank you all for getting me to the point I am at now. I have learned something from each and every one of you and use that daily to teach others. 


\section{TABLE OF CONTENTS}

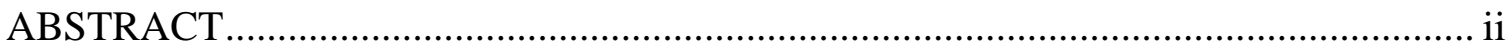

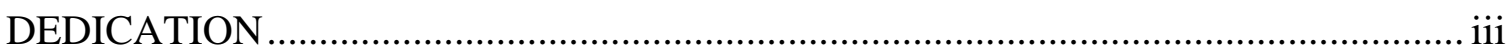

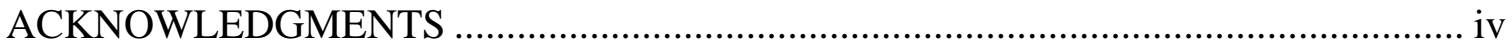

TABLE OF CONTENTS............................................................................... vi

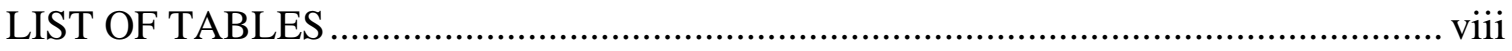

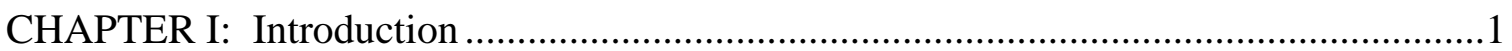

Statement of Problem ........................................................................

Purpose of the Study ........................................................................4

Objective of the Study ......................................................................

Limitations of the Study ....................................................................

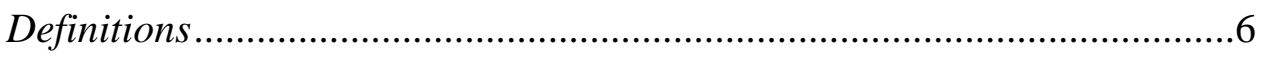

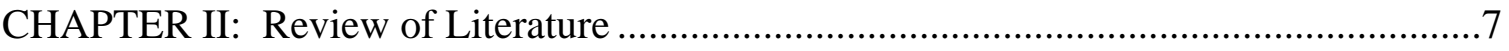

Development of Agricultural Communications ........................................ 7

Demand for Agricultural Communications ............................................8

Agricultural Communications Curriculum Review ..................................9

Need for Curriculum Content Review ...................................................10

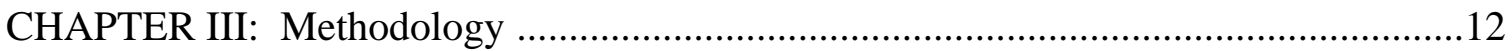

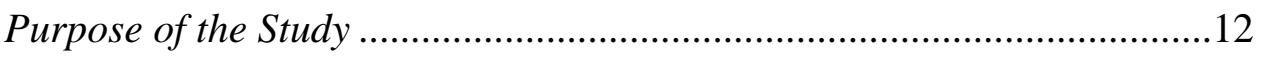

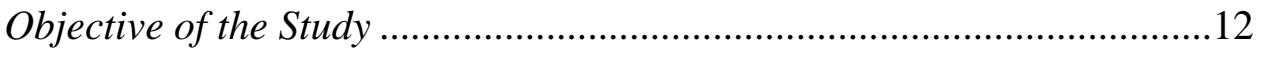

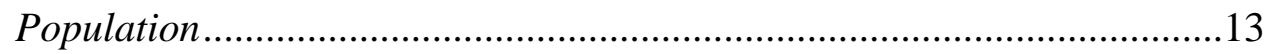

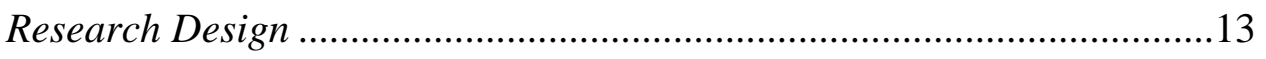

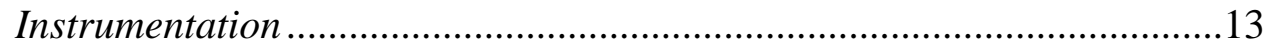


Data Collection ........................................................................................

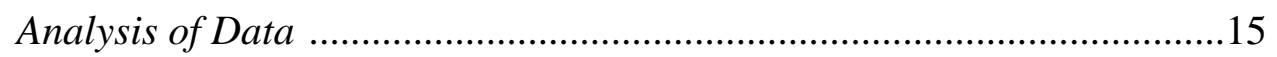

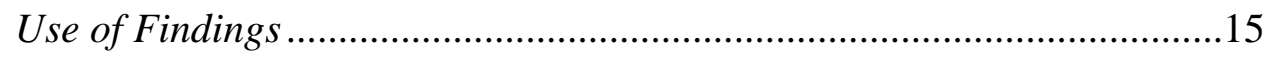

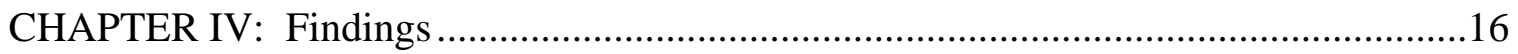

Analysis of Returned Surveys...............................................................17

Demographic Data..........................................................................18

Education, Employment and Training Status ...........................................19

Frequency of Use of Communications Skills .............................................21

Instructional Adequacy of Communications Skills ....................................25

Summary of Research Findings ............................................................28

CHAPTER V: Summary, Conclusions, and Recommendations .........................................30

Summary of Findings ...........................................................................

Conclusions .........................................................................................

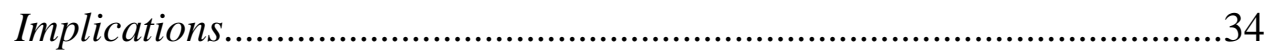

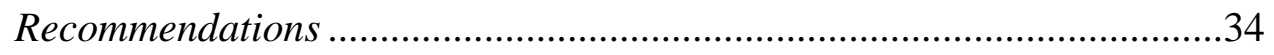

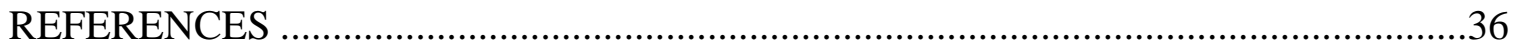

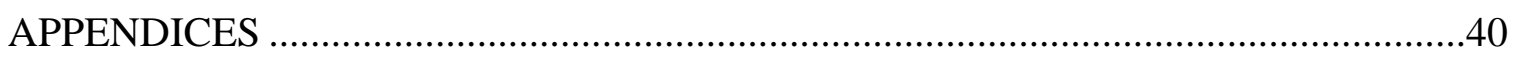

APPENDIX A: Cover letter to Research Population.....................................41

APPENDIX B: Survey Instrument ………………………………….......43

APPENDIX C: Follow-up Cover Letter .......................................................49

APPENDIX D: Second Follow-up/Late Respondent Letter.........................51

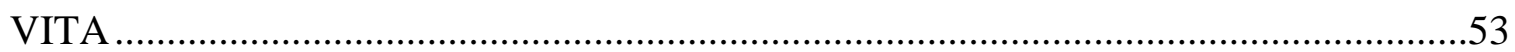




\section{LIST OF TABLES}

Table 1 Demographic Characteristics of Respondents...............................................19

Table 2 Education, Employment and Training Status which Influence Use of Communication Skills

Table 3 Frequency of Use of Communications Skills Taught in Agricultural and Natural Resources Communications.......................................................23

Table 4 Instructional Adequacy of Communications Skills Taught in Agricultural and Natural Resources Communications..... .26 


\section{CHAPTER I}

Introduction

Land-grant universities were created to embody a system of widely accessible higher education for the rural population. The Morrill Act of 1862 established land grant universities that served public demands brought about by the need for agricultural and the mechanical arts. The Hatch Act of 1887 established agricultural experiment stations for the purpose of conducting agricultural research. The first section of the Hatch Act reads:

Be it enacted by the Senate and House of Representatives of the United States of America in Congress assembled, That in order to aid in acquiring and diffusing among the people of the United States useful and practical information on subjects connected with agriculture, and to promote scientific investigation and experiment respecting the principles and application of agricultural science, there shall be established under direction of the college or colleges or agricultural departments of colleges in each State and Territory ... an agricultural experiment station (sec.1 Act of 1887 Establishing Agricultural Experiment Stations).

This legislation indicated that experiment stations had two functions; to conduct scientific investigations in agriculture and to disseminate practical agricultural information. The Hatch Act created a need for the land grant universities to develop academic curricula which could accommodate the educational demands brought about by the creation of experiment stations and their subsequent research.

In the early 1900s universities created agricultural journalism out of a need to disseminate research results to agriculturally related audiences (Bailey \& Evans, 1994). 
The dissemination of agricultural research continues to be paramount with today's academicians. However, as Evans (1975) stated, "One of the realities about being an educator in agricultural communications is that the discipline is hazily defined, academically” (p. 11). The challenge now becomes educating today's agricultural students to meet demands that will be made upon them in their future employment.

Agricultural journalism programs originated with intentions of educating students to pursue journalistic careers (Bailey \& Evans, 1994). As Akers (2000) denotes, "development of a business oriented industry in agriculture, coupled with a lack of knowledge on the part of the general public about agriculture, has generated a tremendous interest in including agricultural communications as part of the curriculum in agricultural education” (p. 3). As curriculum changes occurred, often schools changed their program's notation from journalism to communications (Evans, 1975).

Job requirements and technology have changed the competencies needed by the agricultural communicator, creating a need to examine the curriculum to make it applicable to the students and their future employers (Sprecker \& Rudd, 1997). Paulson and Metzger (1990) add support to curricular examination by adding that aggressive changes in technology indicate a predominate need to review curriculum.

Roxanne Eatinger noted (2001), “Communication is a big part of agriculture. Whether it is selling your corn to the elevator or a manufacturer selling corn flakes to a consumer, communication is key. The farmer or rancher of today must be a savvy businessman to make it” (Hasenauer, p. 1). Buck and Barrick (1995) wrote, "As the profession of agricultural communications continues to develop and refine its mission in society, we must relate this mission to our academic programs” (p. 1). Such statements 
make it apparent that not only must curriculums offer proficient agricultural training, they must also offer students educational opportunities in career enrichment skills such as communications.

Paulson and Metzger (1990) stated that if agriculture curriculums were to meet the needs of the industry, then communication programs must maintain contact with professionals in the field to ascertain the needs and skills required for a career in agricultural communications. Historically there have been studies conducted to identify educational and curricular needs of the agricultural communications student and perceptions as to how to improve programs (Irani \& Scherler, 2002). However, an indepth review of research exhibits a lack of exploration into determining communication skills used during initial employment by students who were educated in agricultural communications.

\section{Statement of the Problem}

Established under the provisions of the Morrill Act of 1862, West Virginia University’s agricultural academic curriculum has evolved to meet the changing societal emphasis from production agriculture to agribusiness. West Virginia University’s Davis College of Agriculture, Forestry, and Consumer Sciences Agricultural and Natural Resources Communication’s course description is as follows: "Procedures and practices in developing, interpreting, and communicating agricultural and natural resources information with emphasis on the use of visual material and effective presentations”(West Virginia University, 2003, p. 285). This course serves as the primary communications course for students enrolled in the Davis College of Agriculture, Forestry, and Consumer Sciences. The agricultural and natural resources 
communications course provides knowledge in the broad area of agriculture communications to eleven undergraduate programs, including but not limited to: Agricultural and Environmental Education, Agricultural Resource Economics, Animal and Food Science, Environmental Protection, Forest Resources Management, PreVeterinary Medicine, Wood Industries, Recreation, Parks, and Tourism, Horticulture, Wildlife and Fisheries Management Agronomy, and Landscape Architecture.

In a study of agribusinesses, Helming (1990) found that communication skills of agricultural graduates were the second highest-ranking attribute desired by the industry. Helming continued to explain that communication weaknesses of agricultural students were due to deficiencies in their degree programs. With such a major impact on the student population and variety of degree programs at West Virginia University, it is paramount to better define what communication skills are being utilized by alumni of the Davis College of Agriculture Forestry and Consumer Science's agricultural and natural resources communications course so as to better prepare future graduates to become competitive agriculturists.

Purpose of the Study

The purpose of the study was to determine communication skills used during initial employment by 2001-2002 graduates of the Davis College of Agriculture, Forestry and Consumer Sciences who were enrolled in the agricultural and natural resources communications (AgEE 421) course. The results of this study will provide a basis for the curriculum content of agricultural communications courses offered in the Davis College of Agriculture, Forestry and Consumer Science. 


\section{Objective of the Study}

The objective of this study was to assess communication skills used during initial employment as perceived by graduates of the Davis College of Agriculture, Forestry, and Consumer Science. As a means of developing this study, answers to the follow questions were sought:

1. What communication skills did graduates regularly practice during their initial employment?

2. What communication skills learned in agricultural and natural resources communications (AgEE 421) were most beneficial?

3. What communication skills were needed by graduates but were not taught in agricultural and natural resources communications (AgEE 421)?

4. Did graduates feel they were adequately educated in agricultural communications?

\section{Limitations of the Study}

The research findings of this study will be limited to alumni of the Davis College of Agriculture, Forestry, and Consumer Science at West Virginia University who graduated in 2001 and 2002 and were enrolled in agricultural and natural resources communications. All participants of this study were educated by the same professor while enrolled in agricultural and natural resources communications (AgEE 421). 


\section{Definitions}

For the purpose of this study, the following terms were defined as follows:

Agricultural Communications: Academic programs that involve agriculture and a variety of communication specializations such as journalism, advertising, public relations, etc. (Bailey-Evans, 1994).

Communication Skills: Identifiable behaviors and knowledge used in an occupation to benefit interpersonal communication.

Initial Employment: Full or part time employment of any discipline gained within three years by graduates upon completion of collegiate education.

Agricultural Education: Also referred to "agriscience education” and "vocational agriculture education”. Systematic instruction that prepares students for successful careers and a lifetime of informed choices in global agriculture, food, fiber and natural resources systems (Reinventing Agricultural Education in the Year 2020, 1999). 


\section{CHAPTER II}

Review of Literature

\section{Development of Agricultural Communications}

Communication is an integral part of nearly all your professional life. On the job, you may use communication to make a sale, demonstrate a product, persuade a client, or explain company procedures to a new employee. As more and more careers focus on "service" instead of manufacturing, the need to be a competent speaker will become even more important for job success (Samovar \& Mills, 1995, p. 5)

Historically, meeting the communication educational needs of collegiate students has posed a challenge. Flatt (1991) concluded, with accelerating changes in technology, it is important to examine communications curriculum to meet the needs of the students, graduates, faculty, and administration. In response, faculty in agriculture, like faculty in many other disciplines, have become keenly aware of this shortcoming and demonstrated efforts to remedy it (Katsman \& Booker, 2003). Katsman and Booker (2003) also noted, "Rather than blaming English departments (traditionally the home of instruction in communication) for shortcomings in students' proficiencies in writing and communication, many programs in agriculture are benefiting from incorporating communication into their discipline-specific courses” (p. 37).

Lockaby and Vernon (1998) noted, agricultural communications programs before 1960 were more narrowly defined in journalistic terms. Over the years however, academic programs have continued to evolve as both agriculture and new communication technologies have developed (Terry \& Bailey-Evans, 1995). "Curricula which were 
originally intended to prepare students for a career as newspaper editors have expanded to involve all communications media and a wide range of activities within those media” (Bailey \& Evans, 1994, p. 17). “As the profession of agricultural communications continues to develop and refine its mission in society, we must relate this mission to our academic programs” (Buck \& Paulson, 1995, p. 1, as cited by Irani \& Scherler, 2002). "The agricultural communications curriculum should continually be expended and updated to reflect the technological advancements of today and tomorrow” (Bailey \& Evans, 1994, p. 93). As agriculture changes, academic curricula must also change to meet educational, societal, and professional demands within the field.

\section{Demand for Agricultural Communications}

There is a tremendous demand for individuals who are skilled in the agricultural field and also possess the ability needed to communicate the concept of agriculture to the public. "It is for this reason that academic programs in agricultural communications have begun to flourish in colleges of agriculture across the United States” (Terry, Vaughn, Vernon, Lockaby, Bailey-Evans, \& Rehrman, 1994, p. 5).

Currently there are approximately 30 colleges which have integrated communications into the discipline of agriculture and offer both undergraduate and graduate degrees in Agriculture Communications. The curricula of the colleges having communication programs are inclusive of courses in journalism, telecommunications, public relations, and additional classes which continue to meet the changing local, regional and national needs, however, such programs often differ substantially as to course 
elements and requirements (Reisner; as cited in Irani and Scherler, p. 12, 2002).

Coulter, Stanton, \& Goecker (1990) found in their evaluation of agriculturally related employment that slightly more than 43,500 new graduates with expertise in food, agricultural, and natural resources are expected each year, leaving an annual shortage of nearly $11 \%$ through the mid-1990s and beyond. Trends show that the greatest agriculturally related employment opportunities will be in the marketing, merchandising, and sales representative fields due to a projected 18\% shortage of graduates (Osmond \& Hoover, 1995).

Most recent changes on emphasis of instruction in agriculture has redirected from production to agribusiness (Case \& Whitaker, 1998). The development of a business oriented industry in agriculture, coupled with a lack of knowledge on the part of the general public about agriculture, has generated a tremendous interest in including agricultural communications as apart of the curriculum (Bailey \& Evans, 1994). Looking into the future of agricultural communications, a projected high demand in the discipline gives weight to the continuation of promoting and evaluating education in the field.

\section{Agricultural Communications Curricular Review}

However, recent changes in the fields of communications and agriculture have created a need for agricultural communications faculty to examine their curricula (Souka 1985; Dillman, 1989). Since 1905 when the first agriculture communications curriculum was developed, there has been no in-depth assessment conducted in order to determine 
what disciplines and competencies need to be included in the agricultural communications curriculum (Bailey \& Evans, 1994).

Evans (1969) stated that identification of subject matter contained within the agricultural communications curriculum has not been fully identified. Reisner (1990) states, “The need for periodic examination of agricultural communications programs and curricula is acute” (p. 10). Finch \& Crunkilton (1989) elaborate this concept by stating that if a curriculum is being revised, it is vital to ensure that the contents reflect the needs of the work force. "If academic curriculum is to meet the needs of the industry, agricultural communications programs must continually survey professionals to determine the needs and skills required for a career in agricultural communications and then adjust curriculum accordingly” (Sprecker, 1997 p. 2).

Need for Curriculum Content Review

Bailey and Evans (1994) conclude, “Only a handful of studies have looked at what courses are taught in agricultural communication (p. 14). A competency-based curriculum was developed by a group of researchers in the early 1990s for agricultural communications programs nationwide (Terry, et al., 1994). In addition to this research, Bailey and Evans (1994) developed a list of disciplinary areas which should be included in agricultural communications programs. Other research conducted by Sprecker (1998) deducted that only a few detailed studies of agricultural communications curricula exist (Nash, 1928; Evans \& Bolick, 1982).

“The review of literature clearly indicates the deficiency of a study devoted solely to agricultural communications to determine what disciplines and competencies should be required for each emphasis area within a core curriculum” (Bailey \& Evans, 1994, p. 23). 
After reviewing the literature available, covering the field of agricultural communications, there is an apparent need to review the content of the curriculum (Flatt, 1991).

The absence of a definition for agricultural communications curriculum content supports research in the area of agricultural communication skills used during initial employment. Identifying curricular content that will meet the needs of students requires defining what communication skills are utilized during employment. The basis of these applied skills will aid in construction of a body of content for a curriculum. 


\section{CHAPTER III}

\section{Methodology}

Purpose of the Study

The purpose of this study was to determine communication skills used during initial employment by graduates of the Davis College of Agriculture, Forestry and Consumer Sciences who received instruction in the broad area of agricultural communications through enrollment in the agricultural and natural resources communications (AgEE 421) course. The results of this study will provide a basis for the curriculum content of agricultural communications courses offered in the Davis College of Agriculture, Forestry and Consumer Sciences.

Objective of the Study

The objective of this study was to assess communication skills used during initial employment as perceived by 2001-2002 graduates of the Davis College of Agriculture, Forestry, and Consumer Sciences, who were enrolled in agricultural and natural resources communications course (AgEE 421). As a means of developing this study, answers to the follow questions were sought:

1. What communication skills did graduates regularly practice during their initial employment?

2. What communication skills learned in agricultural and natural resources communications (AgEE 421) were most beneficial?

3. What communication skills were needed by graduates but were not taught in agricultural and natural resources communications (AgEE 421)? 
4. Did graduates feel they were adequately educated in agricultural communications?

\section{Population}

The target population of this study was all 2001 and $2002(\mathrm{~N}=70)$ graduates from West Virginia University Davis College of Agriculture, Forestry and Consumer Science who were enrolled in agricultural and natural resources communications (AgEE 421) during their collegiate careers.

\section{Research Design}

Descriptive survey research methods were used to collect data from the target population. "Descriptive research is not generally directed toward hypothesis testing. The aim is to "describe, 'what exists' with respect to variables or conditions in a situation” (Ary, Jacobs, \& Rzavieh, 1990, p. 381). This study was conducted to define what communications needs exist in the stages of initial employment for graduates of West Virginia University.

\section{Instrumentation}

A questionnaire (see Appendix B) was mailed to the target population of 70, 2001-2002 graduates of the Davis College of Agriculture, Forestry and Consumer Science. The survey consisted of three sections. The first section of the survey involved rating the frequency of use of communication skills taught in AgEE 421 during initial employment and the adequacy with which those skills were taught. The rating scale was the following for the frequency of use: 5- always, 4- often, 3- occasionally, 2- rarely, and 1- never. The rating scale was the following for the adequacy of instruction: 4- very adequate, 3- somewhat adequate, 2- adequate, and 1- not adequate. 
The second section of the survey gathered information about personal communication skills that were needed during initial employment in the form of openended questions. The third section requested demographic information on the respondents.

Members of the graduate committee evaluated the instrument to establish its face and content validity. Requirements of the Human Subjects Review Board of West Virginia University were met. Internal instrument reliability was determined from an analysis of data from the target population using Cronbach’s Alpha. Cronbach’s Alpha for the first measurement scale based on frequency of use was 0.93 . The second measurement scale based on adequacy of teaching scored a Cronbach’s Alpha of 0.96 . An alpha coefficient rating 0.80 or better by analysis of Cronbach's Alpha shows an exemplary internal consistency estimate of instrument reliability (Robinson, Shaver, \& Wrightsman, 1991). An independent $t$-test was performed to analyze responses from early/late respondents, no significant differences were found $(\alpha \leq 0.05)$.

\section{Data Collection}

Following Dillman's protocol for data collection, the researcher made three attempts at gathering data from the target population. Each collection attempt was limited to a two-week response deadline and included a cover letter (see Appendix A), instrument (see Appendix B), and self-addressed stamped return envelope. The total response rate was $54 \%$. 
Analysis of Data

A numerical code was assigned to each population member prior to the initial mailing. This code enabled the researcher to document each survey received. The code was destroyed to protect the anonymity of the research participant.

Data were entered into an Excel spreadsheet through the assignment of numerical values to each variable in the instrument. Data collected were analyzed using Statistical Package for Social Sciences (SPSS). Open-ended question responses were documented in full text format. Descriptive analyses including frequencies, percentages, and means were used to evaluate numerical data to allow for conversion into narrative form. Use of Findings

The findings of this study will be utilized to create alterations to the curriculum of AgEE 421, agriculture communication course at West Virginia University. The results will also contribute to the possible creation of a second course in agriculture communications at West Virginia University if deemed necessary. 


\section{CHAPTER IV}

\section{Findings}

The purpose of this study was to determine communication skills used during initial employment by graduates of the Davis College of Agriculture, Forestry and Consumer Sciences who received education in the broad area of agricultural communications through enrollment in the agricultural and natural resources communications (AgEE 421) course. This study was limited to students who were enrolled in agricultural and natural resources communications (AgEE 421) in 2001 and 2002 who have graduated from West Virginia University.

The primary objective of this study was to evaluate the use of communications skills taught in agricultural and natural resources communications (AgEE 421). In addition to frequency of use, this study also determined the adequacy with which these skills were taught in agricultural and natural resources communications (AgEE 421). Secondary objectives for this study included:

1. What communication skills did graduates regularly practice during their initial employment?

2. What communication skills learned in agricultural and natural resources communications (AgEE 421) were most beneficial?

3. What communication skills were needed by graduates but were not taught in agricultural and natural resources communications (AgEE 421)?

4. Did graduates feel they were adequately educated in agricultural communications? 


\section{Analysis of Returned Surveys}

The target population of this study was for this study consisted of 70 West Virginia University's 2001 and 2002 graduates who were enrolled in Davis College of Agriculture, Forestry and Consumer Science’s agricultural and natural resources communications (AgEE 421) course. The target population was the accessible population and a census study was conducted. Thirty-eight (54\%) questionnaires were returned. Three attempts were made at collecting data. Each attempt included a cover letter, an instrument, and a self-addressed stamped return envelope. An initial cover letter (see Appendix A) explained the purpose of this study and instructed respondents about the questionnaire. The questionnaire (see Appendix B) was sent with each mailing and data collected via responses from the study population. A response rate of $22 \%$ ( $N=16)$ occurred from the first collection attempt. A second cover letter (see Appendix C) in the same format along with the instrument and self-addressed stamped return envelope was sent to respondents who did not submit their initial survey prior to the collection deadline. A response rate of $20 \%(N=11)$ occurred during the second collection attempt. A third cover letter (see Appendix D) was sent to respondents who had not replied to the first two data collection attempts. The third mailing of the cover letter, instrument and self-addressed stamped return envelope was an attempt to collect data from the remaining 43 population members who had not responded to the two prior mailings. A non-response collection rate of $28 \%(N=12)$ resulted from the final collection attempt.

Data were entered into an Excel spreadsheet. Data were analyzed using the Statistical Package for Social Sciences (SPSS). Open-ended question responses were 
recorded in full. Descriptive analyses including frequencies, percentages, and means were used to evaluate numerical data.

A $t$-test was used to compare early and late respondents' perceptions of the needed communications skill during initial employment. No significant differences were distinguished when comparing early and late respondents in this study, therefore, generalizations were made to the target population.

\section{Demographic Data}

The target population of this study consisted of all 2001 and 2002 West Virginia University graduates who were enrolled in agricultural and natural resources communications (AgEE 421) during their collegiate career $(N=70)$. A census study was conducted and all 70 population members were included in the data collection process. The participants were asked their gender, age and location of initial employment.

Twenty-one of the respondents (55.3\%) were male, while 17 (44.7\%) were female. Eighteen of the respondents (47.4\%) were 25 to 29 years of age, 17 (44.7\%) were ages 20 to 24 years old, and three (7.9\%) were 35 years of age or older. Of the 38 respondents, 17 (50.0\%) acquired initial employment in West Virginia, and four (11.8\%) of the respondents acquired initial employment in Pennsylvania. Four respondents (11.8\%) acquired initial employment in Virginia. Three respondents (8.8\%) were initially employed in New York, and six (17.4\%) of the respondents acquired initial employment in various other states. The data were reported in Table 1. 
Table 1

Demographic Characteristics of Respondents

\begin{tabular}{|c|c|c|}
\hline & \multicolumn{2}{|c|}{ Total } \\
\hline & $N$ & $\%$ \\
\hline \multicolumn{3}{|l|}{ Gender } \\
\hline Male & 21 & 55.3 \\
\hline Female & 17 & 44.7 \\
\hline \multicolumn{3}{|l|}{ Age } \\
\hline 20 to 24 years & 17 & 44.7 \\
\hline 25 to 29 years & 18 & 47.4 \\
\hline 35 to 39 years & 2 & 5.3 \\
\hline 40 to 44 years & 1 & 2.6 \\
\hline \multicolumn{3}{|c|}{ State of Initial Employment } \\
\hline West Virginia & 17 & 50.0 \\
\hline Pennsylvania & 4 & 11.8 \\
\hline Virginia & 4 & 11.8 \\
\hline New Jersey & 1 & 2.9 \\
\hline New York & 3 & 8.8 \\
\hline Washington, DC & 1 & 2.9 \\
\hline California & 1 & 2.9 \\
\hline Colorado & 1 & 2.9 \\
\hline Florida & 1 & 2.9 \\
\hline Oregon & 1 & 2.9 \\
\hline
\end{tabular}

\section{Education, Employment and Training Status}

The degrees and majors of the respondents were reported in Table 2.

Employment status and notation of additional training in communications were also analyzed and reported (see Table 2). Of the total respondents, the highest degree earned by 31 respondents (81.6\%) was a Bachelor’s degree, with 7 (18.4\%) earning a Master’s degree. While enrolled in agricultural and natural resources communications, 35 of the respondents (92.1\%) were undergraduate students and 3 (7.9\%) were graduate students. 
Respondents reported their major upon graduation. Results were analyzed and presented in Table 2. There were twelve potential majors listed on the instrument. Respondents used eight of the twelve categories to report their majors. Seventeen (44.7\%) of the respondents reported “Other” as their major, five (13.2\%) were Agricultural \& Environmental Education majors, and four (10.5\%) were Wildlife and Fisheries Management Majors. Agricultural Resources Economics and Forest Resources Management each had three (7.9\%) respondents and there were two (5.3\%) respondents

Table 2

Education, Employment and Training Status

\begin{tabular}{lrr}
\hline & \multicolumn{2}{c}{ Total } \\
\cline { 2 - 3 } & $N$ & $\%$ \\
\hline Status while Enrolled in AgEE 421 & 35 & 92.1 \\
Undergraduate & 3 & \\
Graduate & & \\
Highest Degree Earned & 31 & 81.6 \\
Bachelor's Degree & 7 & 18.4 \\
Master's Degree & & \\
Major & 5 & 13.2 \\
Agricultural \& Environmental Education & 4 & 10.5 \\
Wildlife and Fisheries Management & 3 & 7.9 \\
$\quad$ Agricultural Resource Economics & 3 & 5.9 \\
Forest Resources Management & 2 & 5.3 \\
Pre-Veterinary Pre-Medicine & 2 & 5.3 \\
Recreation, Parks and Tourism Management & 2 & 44.7 \\
Animal and Food Science & 17 & 85.7 \\
Other & & 14.3 \\
Employment Status & 30 & 74.3 \\
Full-time & 5 & 25.7 \\
Part-time & & \\
Additional Training in Communications & 26 & \\
$\quad$ No & 9 & \\
Yes & & \\
\end{tabular}


from each of the following majors; Animal and Food Science; Pre-Veterinary/PreMedicine; and Recreation, Parks, and Tourism Management.

Employment status was also reported in Table 2. Thirty (85.7\%) of the respondents held full-time initial employment and five (14.3\%) held part-time initial employment. Twenty-six (74.3\%) of the respondents had received additional training (see Table 2).

Frequency of Use of Communications Skills Taught

The respondents' perceptions of communications skills use during initial employment were analyzed by mean and ranked (see Table 3). Responses were averaged and the mean of each item was scaled and reported within a range to determine the frequency of use. The skills used most often $(M=3.51-4.50)$; based on average were, “actively applied general AgEE 421 skills during my initial employment” $(M=4.49)$; “apply knowledge of verbal communication” ( $M=4.47)$; “AgEE 421 skills benefited me during my initial employment” ( $M=4.41)$; “apply knowledge of nonverbal communication” ( $M=4.39)$; “apply knowledge of listening” $(M=4.34)$; “communicate interpersonally" ( $M=4.32)$; “communicate with small groups” $(M=4.21)$; " respond to emails” ( $M=4.13)$; “communicate via telephone” $(M=4.08)$, and "write a cover letter with the AgEE 421 format” $(M=3.79)$. Fourteen of the skills listed had a mean score within 2.51-3.50 and were used occasionally by the respondents. There were eight skills that were averaged and had a mean score of 1.51-2.50, these skills were used rarely used by respondents: "write speeches inclusive of introduction, body and conclusion" $(M=$ 2.50); using tables and graphs while presenting” $(M=2.24)$; "act as an interviewer" ( $M=$ 
2.24); "use power-point while presenting” ( $M=2.18)$; "present to groups of 21-40 people” $(M=2.08)$; “introduce a guest speaker” $(M=1.92)$; “use transparencies while presenting” ( $M=1.92)$; "give/accept an award" $(M=1.82)$, and "write resignation letters with AgEE 421 format” $(M=1.78)$. A majority of the respondents reported they never used, "present to groups of 41 or more people," which ranked lowest $(M=1.47)$. However, thirteen respondents did report using this skill to some degree. 
Table 3

Frequency of Use of Communications Skills Taught

\begin{tabular}{|c|c|c|c|c|c|c|c|c|c|c|c|}
\hline & \multicolumn{2}{|c|}{ Never } & \multicolumn{2}{|c|}{ Rarely } & \multicolumn{2}{|c|}{ Occasionally } & \multicolumn{2}{|c|}{ Often } & \multicolumn{2}{|c|}{ Always } & \multirow[t]{2}{*}{ Mean } \\
\hline & $N$ & $\%$ & $N$ & $\%$ & $N$ & $\%$ & $N$ & $\%$ & $N$ & $\%$ & \\
\hline $\begin{array}{l}\text { Actively apply gen. AgEE421 skills } \\
\text { during my initial employment }\end{array}$ & 1 & 2.7 & 0 & 0 & 3 & 8.1 & 9 & 24.3 & 24 & 64.9 & 4.49 \\
\hline $\begin{array}{l}\text { Apply knowledge of verbal } \\
\text { communication }\end{array}$ & 0 & 0 & 0 & 0 & 7 & 18.4 & 6 & 15.8 & 25 & 65.8 & 4.47 \\
\hline $\begin{array}{l}\text { Comm. skills from AgEE421 } \\
\text { benefited me during initial } \\
\text { employment }\end{array}$ & 2 & 5.4 & 1 & 2.7 & 2 & 5.4 & 7 & 18.9 & 25 & 67.6 & 4.41 \\
\hline $\begin{array}{l}\text { Apply knowledge of nonverbal } \\
\text { communication }\end{array}$ & 0 & .0 & 1 & 2.6 & 6 & 15.8 & 8 & 21.1 & 23 & 60.5 & 4.39 \\
\hline Apply knowledge of listening & 1 & 2.6 & 0 & .0 & 8 & 21.1 & 5 & 13.2 & 24 & 63.2 & 4.34 \\
\hline Communicate interpersonally & 0 & .0 & 1 & 2.6 & 3 & 7.9 & 17 & 44.7 & 17 & 44.7 & 4.32 \\
\hline Communicate with small groups & 1 & 2.6 & 1 & 2.6 & 4 & 10.5 & 15 & 39.5 & 17 & 44.7 & 4.21 \\
\hline Write-respond to emails & 3 & 7.9 & 0 & .0 & 6 & 15.8 & 9 & 23.7 & 20 & 52.6 & 4.13 \\
\hline Communicate via telephone & 1 & 2.6 & 1 & 2.6 & 9 & 23.7 & 10 & 26.3 & 17 & 44.7 & 4.08 \\
\hline $\begin{array}{l}\text { Write cover letters with AgEE } 421 \\
\text { format }\end{array}$ & 6 & 15.8 & 1 & 2.6 & 7 & 18.4 & 5 & 13.2 & 19 & 50.0 & 3.79 \\
\hline Conduct demonstrations & 7 & 18.4 & 4 & 10.5 & 6 & 15.8 & 7 & 18.4 & 14 & 36.8 & 3.45 \\
\hline $\begin{array}{l}\text { Write résumés with AgEE } 421 \\
\text { format }\end{array}$ & 6 & 15.8 & 3 & 7.9 & 11 & 28.9 & 5 & 13.2 & 13 & 34.2 & 3.42 \\
\hline Speak to a group for $3-5$ minutes & 7 & 18.4 & 5 & 13.2 & 7 & 18.4 & 6 & 15.8 & 13 & 34.2 & 3.34 \\
\hline Use a digital camera & 6 & 15.8 & 6 & 15.8 & 8 & 21.1 & 7 & 18.4 & 11 & 28.9 & 3.29 \\
\hline Write follow-up letters with AgEE & & & & & & & & & & & \\
\hline 421 format & 9 & 23.7 & 6 & 15.8 & 5 & 13.2 & 6 & 15.8 & 12 & 31.6 & 3.16 \\
\hline
\end{tabular}


Table 3 (continued)

Frequency of Use of Communications Skills Taught

\begin{tabular}{|c|c|c|c|c|c|c|c|c|c|c|c|}
\hline & \multicolumn{2}{|c|}{ Never } & \multicolumn{2}{|c|}{ Rarely } & \multicolumn{2}{|c|}{ Occasionally } & \multicolumn{2}{|c|}{ Often } & \multicolumn{2}{|c|}{ Always } & \multirow[t]{2}{*}{ Mean } \\
\hline & $N$ & $\%$ & $N$ & $\%$ & $N$ & $\%$ & $N$ & $\%$ & $N$ & $\%$ & \\
\hline Present to groups of 5-20 people & 8 & 21.1 & 5 & 13.2 & 7 & 18.4 & 11 & 28.9 & 7 & 18.4 & 3.11 \\
\hline Speak to a group for 8-10 minutes & 10 & 27.0 & 2 & 5.4 & 9 & 24.3 & 7 & 18.9 & 9 & 24.3 & 3.08 \\
\hline Use a 35 mm camera & 8 & 21.1 & 4 & 10.5 & 14 & 36.8 & 6 & 15.8 & 6 & 15.8 & 2.95 \\
\hline Negotiate sales & 14 & 36.8 & 4 & 10.5 & 5 & 13.2 & 7 & 18.4 & 8 & 21.1 & 2.76 \\
\hline $\begin{array}{l}\text { Use the communication strategy } \\
\text { plan }\end{array}$ & 11 & 30.6 & 2 & 5.6 & 12 & 33.3 & 8 & 22.2 & 3 & 8.3 & 2.72 \\
\hline $\begin{array}{l}\text { Use audiovisual-media equipment } \\
\text { Write acceptance letters with AgEE }\end{array}$ & 10 & 27.0 & 9 & 24.3 & 6 & 16.2 & 7 & 18.9 & 5 & 13.5 & 2.68 \\
\hline 421 format & 17 & 44.7 & 3 & 7.9 & 4 & 10.5 & 5 & 13.2 & 9 & 23.7 & 2.63 \\
\hline $\begin{array}{l}\text { Speak to a group for } 20 \text { minutes or } \\
\text { more }\end{array}$ & 15 & 39.5 & 6 & 15.8 & 6 & 15.8 & 4 & 10.5 & 7 & 18.4 & 2.53 \\
\hline $\begin{array}{l}\text { Write speeches inclusive of } \\
\text { introduction, body and conclusion }\end{array}$ & 15 & 39.5 & 6 & 15.8 & 7 & 18.4 & 3 & 7.9 & 7 & 18.4 & 2.50 \\
\hline Use tables-graphs while presenting & 19 & 50.0 & 3 & 7.9 & 8 & 21.1 & 4 & 10.5 & 4 & 10.5 & 2.24 \\
\hline Act as an interviewer & 20 & 52.6 & 4 & 10.5 & 4 & 10.5 & 5 & 13.2 & 5 & 13.2 & 2.24 \\
\hline Use PowerPoint while presenting & 21 & 55.3 & 3 & 7.9 & 4 & 10.5 & 6 & 15.8 & 4 & 10.5 & 2.18 \\
\hline Present to groups of $21-40$ people & 16 & 42.1 & 11 & 28.9 & 5 & 13.2 & 4 & 10.5 & 2 & 5.3 & 2.08 \\
\hline Introduce a guest speaker & 24 & 63.2 & 5 & 13.2 & 1 & 2.6 & 4 & 10.5 & 4 & 10.5 & 1.92 \\
\hline Use transparencies while presenting & 22 & 57.9 & 3 & 7.9 & 8 & 21.1 & 4 & 10.5 & 1 & 2.6 & 1.92 \\
\hline Give-accept an award & 24 & 63.2 & 3 & 7.9 & 6 & 15.8 & 4 & 10.5 & 1 & 2.6 & 1.82 \\
\hline Write resignation letters with AgEE & & & & & & & & & & & \\
\hline 421 format & 25 & 67.6 & 4 & 10.8 & 3 & 8.1 & 1 & 2.7 & 4 & 10.8 & 1.78 \\
\hline $\begin{array}{l}\text { Present to groups of } 41 \text { or more } \\
\text { people }\end{array}$ & 25 & 65.8 & 9 & 23.7 & 3 & 7.9 & 1 & 2.6 & 0 & .0 & 1.47 \\
\hline
\end{tabular}

Rating scale: 1-Never, 2-Rarely, 3-Occasionally, 4- Often, 5-Always 


\section{Instructional Adequacy of Communications Skills Taught}

The respondents' perceptions of adequacy of instruction in agricultural and natural resources communications were analyzed and ranked (see Table 4). The mean of each item was scaled and reported within a range to determine the adequacy of instruction. Responses for each item were averaged and the skills that were ranked as being taught very adequately fell within the range of 3.51-4.00. They included, "write résumé with AgEE 421 format" ( $M=3.78)$; "write cover letters with AgEE 421 format" ( $M$ = 3.78); “AgEE 421 benefited me during my initial employment” $(M=3.77)$; "present to groups of 5-20" $(M=3.76)$; "actively apply general AgEE 421 skills during my initial employment” $(M=3.74)$; "write follow-up letters with AgEE 421 format” ( $M$ = 3.70); "speak to a group for 3-5 minutes” ( $M=3.69)$; “apply knowledge of verbal communication” ( $M=3.67)$; “apply knowledge of listening” ( $M=3.65)$; “apply knowledge of nonverbal communication” ( $M=3.64)$; "speak to a group for 8-10 minutes" $(M=3.62)$; "write speeches inclusive of a introduction, body and conclusion” ( $M=3.59)$; “use the communication strategy plan” ( $M=3.59) ;$ "write acceptance letters with the AgEE 421 format” $(M=3.57)$; “communicate interpersonally” $(M=3.54)$; "write resignation letters with AgEE 421 format" ( $M=3$.54), and "give or accept an award” $(M=3.53)$. Responses were averaged and the remaining sixteen skills were found to be taught adequately with a mean score ranging within 2.51-3.50. There were no skills ranked as being taught somewhat adequately or not adequate. 
Table 4

Instructional Adequacy of Communications Skills Taught

\begin{tabular}{|c|c|c|c|c|c|c|c|c|c|}
\hline & \multicolumn{2}{|c|}{ Not Adequate } & \multicolumn{2}{|c|}{$\begin{array}{l}\text { Somewhat } \\
\text { Adequate }\end{array}$} & \multicolumn{2}{|c|}{ Adequate } & \multicolumn{2}{|c|}{ Very Adequate } & \multirow[t]{2}{*}{ Mean } \\
\hline & $N$ & $\%$ & $N$ & $\%$ & $N$ & $\%$ & $N$ & $\%$ & \\
\hline Write résumés with AgEE 421 format & 0 & 0 & 1 & 2.8 & 6 & 16.7 & 29 & 80.6 & 3.78 \\
\hline Write cover letters with AgEE 421 format & 0 & 0 & 2 & 5.4 & 4 & 10.8 & 31 & 83.8 & 3.78 \\
\hline Comm. skills from AgEE 421 benefited me & 0 & 0 & 2 & 5.7 & $\begin{array}{l}4 \\
9\end{array}$ & 11.4 & $\begin{array}{l}29 \\
28\end{array}$ & $\begin{array}{l}82.9 \\
75.7\end{array}$ & $\begin{array}{l}3.77 \\
276\end{array}$ \\
\hline $\begin{array}{l}\text { Present to groups of 5-20 people } \\
\text { Actively applied gen. AgEE421 skills during }\end{array}$ & 0 & 0 & 0 & 0 & 9 & 24.3 & 28 & 75.7 & 3.76 \\
\hline my initial employment & 0 & 0 & 1 & 2.9 & 7 & 20.6 & 26 & 76.5 & 3.74 \\
\hline Write follow-up letters with AgEE 421 format & 0 & 0 & 1 & 2.7 & 9 & 24.3 & 27 & 73.0 & 3.70 \\
\hline Speak to a group for 3-5 minutes & 0 & 0 & 0 & 0 & 11 & 30.6 & 25 & 69.4 & 3.69 \\
\hline Apply knowledge of verbal communication & 0 & 0 & 1 & 2.8 & 10 & 27.8 & 25 & 69.4 & 3.67 \\
\hline Apply knowledge of listening & 0 & 0 & 2 & 5.4 & 9 & 24.3 & 26 & 70.3 & 3.65 \\
\hline Apply knowledge of nonverbal communication & 0 & 0 & 2 & 5.6 & 9 & 25.0 & 25 & 69.4 & 3.64 \\
\hline Speak to a group for 8-10 minutes & 0 & 0 & 1 & 2.7 & 12 & 32.4 & 24 & 64.9 & 3.62 \\
\hline $\begin{array}{l}\text { Write speeches inclusive of introduction, body } \\
\text { and conclusion }\end{array}$ & 0 & 0 & 0 & 0 & 15 & 40.5 & 22 & 59.5 & 3.59 \\
\hline Use the communication strategy plan & 0 & 0 & 1 & 2.9 & 12 & 35.3 & 21 & 61.8 & 3.59 \\
\hline Write acceptance letters with AgEE 421 format & 0 & 0 & 1 & 2.7 & 14 & 37.8 & 22 & 59.5 & 3.57 \\
\hline Communicate interpersonally & 0 & 0 & 1 & 2.7 & 15 & 40.5 & 21 & 56.8 & 3.54 \\
\hline Write resignation letters with AgEE 421 format & 0 & 0 & 2 & 5.7 & 12 & 34.3 & 21 & 60.0 & 3.54 \\
\hline Give-accept an award & 1 & 2.9 & 3 & 8.8 & 7 & 20.6 & 23 & 67.6 & 3.53 \\
\hline Communicate with small groups & 0 & 0 & 3 & 8.1 & 13 & 35.1 & 21 & 56.8 & 3.49 \\
\hline Introduce a guest speaker & 1 & 2.9 & 1 & 2.9 & 13 & 38.2 & 19 & 55.9 & 3.47 \\
\hline Conduct demonstrations & 2 & 5.6 & 3 & 8.3 & 8 & 22.2 & 23 & 63.9 & 3.44 \\
\hline Use transparencies while presenting & 1 & 2.9 & 4 & 11.8 & 9 & 26.5 & 20 & 58.8 & 3.41 \\
\hline Use a $35 \mathrm{~mm}$ camera & 1 & 2.7 & 4 & 10.8 & 12 & 32.4 & 20 & 54.1 & 3.38 \\
\hline
\end{tabular}


Table 4 (Continued)

Instructional Adequacy of Communications Skills Taught

\begin{tabular}{|c|c|c|c|c|c|c|c|c|c|}
\hline & \multicolumn{2}{|c|}{ Not Adequate } & \multicolumn{2}{|c|}{$\begin{array}{l}\text { Somewhat } \\
\text { Adequate }\end{array}$} & \multicolumn{2}{|c|}{ Adequate } & \multicolumn{2}{|c|}{ Very Adequate } & \multirow[t]{2}{*}{ Mean } \\
\hline & $N$ & $\%$ & $N$ & $\%$ & $N$ & $\%$ & $N$ & $\%$ & \\
\hline Present to groups of 21-40 people & 1 & 2.8 & 3 & 8.3 & 14 & 38.9 & 18 & 50.0 & 3.36 \\
\hline Communicate via telephone & 2 & 5.4 & 2 & 5.4 & 15 & 40.5 & 18 & 48.6 & 3.32 \\
\hline Speak to a group for 20 minutes or more & 1 & 2.7 & 5 & 13.5 & 12 & 32.4 & 19 & 51.4 & 3.32 \\
\hline Use audiovisual-media equipment & 1 & 3.0 & 5 & 15.2 & 10 & 30.3 & 17 & 51.5 & 3.30 \\
\hline Use tables-graphs while presenting & 1 & 2.9 & 5 & 14.3 & 12 & 34.3 & 17 & 48.6 & 3.29 \\
\hline Present to groups of 41 or more people & 1 & 2.8 & 6 & 16.7 & 11 & 30.6 & 18 & 50.0 & 3.28 \\
\hline Write-respond to emails & 2 & 5.6 & 4 & 11.1 & 12 & 33.3 & 18 & 50.0 & 3.28 \\
\hline Use a digital camera & 1 & 2.7 & 5 & 13.5 & 14 & 37.8 & 17 & 45.9 & 3.27 \\
\hline Act as an interviewer & 1 & 2.9 & 8 & 22.9 & 9 & 25.7 & 17 & 48.6 & 3.20 \\
\hline Negotiate sales & 2 & 5.6 & 4 & 11.1 & 17 & 47.2 & 13 & 36.1 & 3.14 \\
\hline Use PowerPoint while presenting & 6 & 17.1 & 4 & 11.4 & 11 & 31.4 & 14 & 40.0 & 2.94 \\
\hline
\end{tabular}

Rating Scale: 1-Not Adequate, 2-Somewhat Adequate, 3-Adequate, 4-Very Adequate 
Respondents were asked what communications skills they regularly practiced during initial employment that were not taught but they felt should be included in the agricultural and natural resources communications course curriculum. The open-ended responses were grouped and four skills dominated the responses received. Respondents indicated public relations practices were skills needed during initial employment that were not taught in agricultural and natural resources communications. Basic interpersonal communications skills were also listed as skills respondents felt would have been beneficial to include in the course. One respondent wrote, "One on one communication with other employees, supervisors, and staff would benefit anyone in initial employment." Another skill which respondents felt should be added to the course curriculum was sales negotiation. As one respondent replied, "Communication with people who have no idea who you are (sales, leasing, etc.).” Conflict resolution was a skill area which respondents identified that should be included in the curriculum of agricultural and natural resources communications. "Addressing issues with the general public often involves simple or precarious situations. Teaching communication skills that deal with conflict resolution would be beneficial.” Another respondent wrote, "Conflict resolution or deescalating situations involving angry patrons should be added.”

\section{Summary of Research Findings}

This research study was designed to identify demographic information and rank the frequency of use of communication skills during initial employment. The responses indicated that the study group was equally male and female and predominantly between the ages of 20 to 30 years old. Half of the respondents found initial employment in West Virginia and a majority of the respondents were full time employees in their initial 
positions. A majority of the respondents were undergraduate students who had received no additional training in communications. 


\section{CHAPTER V}

Summary, Conclusions, and Recommendation

The purpose of this study was to determine communication skills used during initial employment by graduates of the Davis College of Agriculture, Forestry and Consumer Sciences who received education in the broad area of agricultural communications through enrollment in the agricultural and natural resources communications (AgEE 421) course. The target population which was the accessible population was 70 graduates of West Virginia University from 2001 and 2002.

The importance of providing communications skills to meet the demands in initial employment has become a prevalent concern of agriculture communications courses.

"The agricultural communications curriculum should continually be expanded and updated to reflect the technological advancements of today and tomorrow” (Bailey \& Evans, 1994, p. 93).

The primary objective of this study was to evaluate the use of communications skills taught in agricultural and natural resources communications (AgEE 421). In addition to frequency of use, this study also determined the adequacy with which these skills were taught in agricultural and natural resources communications (AgEE 421). Secondary objectives for this study included:

1. What communication skills did graduates regularly practice during their initial employment?

2. What communication skills learned in agricultural and natural resources communications (AgEE 421) were most beneficial? 
3. What communication skills were needed by graduates but were not taught in agricultural and natural resources communications (AgEE 421)?

4. Did graduates feel they were adequately educated in agricultural communications?

\section{Summary of Findings}

The respondents’ demographic characteristics were as follows: The study group possessed gender equality, with slightly over half of the respondents being male and slightly less than half were female. A majority of the group was between the ages 20-30 years of age. Half of the respondents found initial employment in West Virginia, while half of the respondents found initial employment outside of West Virginia. Four-fifths of the study group were employed full-time in their initial employment.

A majority of the study group were undergraduates when they were enrolled in agricultural and natural resources communications. Slightly less than four-fifths of the respondents also reported the highest degree they earned was a Bachelor's degree. The study group was composed of respondents who earned a variety of degrees upon graduation, however slightly less than half classified themselves as “other” when reporting their majors.

Over half of the respondents reported that they had actively applied communications skills learned in agricultural and natural resources communications. A majority noted that the skills learned in agricultural and natural resources communications benefited them during initial employment. From the listed skills ( $N=33$ ), on average ten skills were reported as used often during their initial employment, 
13 skills were used occasionally, nine skills were rarely used and one skill on average was never used by the study group during initial employment.

When the adequacy of instruction in agricultural and natural resources communications was addressed, slightly less than four-fifths of the respondents reported that the general skills taught benefited them during initial employment and were taught very adequately. Three-fourths of the study group reported they were able to actively apply skills learned in agricultural and natural resources communications, which were reported to be very adequately taught. From the listed skills ( $N=33$ ), 17 skills were taught very adequately according to respondents and 16 skills were reported as being taught adequately. On average, there were no skills listed that the respondents reported as being taught either somewhat adequately or not adequately on average. Participants were invited to comment on any additional perceptions they had about agricultural and natural resources communications. Many of the comments praised the benefits of the course:

- "I used all skills taught in AgEE this past year with my students. I do use many hands on educational speeches and demonstrations.” [sig]

- "The techniques I learned in AgEE 421 have been very beneficial in communicating with my patients. There were no other communication techniques that I have needed that I did not learn in AgEE 421.”

- "The class was very comprehensive covering both the non-verbal and verbal portions of social interactions.”

- “AgEE 421 should be a required course.” 
Other open-ended questions addressed communication skills respondents felt should be added to the course that were not taught in agricultural and natural resources communications. Respondents predominately reported that public relations practices, basic interpersonal communications, conflict resolution and sales negotiation were used frequently during their initial employment and should be added to the course's curriculum.

\section{Conclusions}

Based upon the results of this study, the following conclusions were drawn:

1. Agricultural and natural resources communications teaches communication skills which are frequently used during initial employment.

2. Most of the communication skills taught in agricultural and natural resources communications are taught very adequately.

3. Over half of the communication skills in this study were used during initial employment and only one skill was rarely used.

4. Significant numbers (over 75\%) of the respondents reported the communications skills learned in agricultural and natural resources communications were actively applied and beneficial.

5. There were four additional skills not taught in agricultural and natural resources communications which a majority of the respondents reported as being needed during initial employment, those skills were public relations practices, basic interpersonal communications, conflict resolution and sales negotiation. 


\section{Implications}

The results of this study supported the beneficial outcomes of enrollment in agricultural and natural resources communications. The review of literature also supported the importance of acquiring educational training in communications skills to benefit initial employment positions. A majority of the skills taught in agricultural and natural resources communications were used during initial employment. The skills which were not used in initial employment were generally not viewed as applicable to beginning employment opportunities. Due to the breadth of the course, some communication knowledge and skills would not normally be applied during initial employment. The respondents' report of all listed skills as being taught adequately or very adequately implied that the instructional influence of teachers can affect adherence and application of skills and knowledge. Data indicates that agricultural and natural resources communications has a broad scope of impact on students throughout the college, not exclusive to the degree programs listed.

\section{Recommendations}

Based on the results of this study the following recommendations were made:

1. Further research should be conducted to determine the benefits of the communications skills taught in agricultural and natural resources communications.

2. This study should be replicated on additional graduates of West Virginia University Davis College of Agriculture, Forestry and Consumer Sciences who were enrolled in agricultural and natural resources communications. 
3. Additional research should be conducted to compare the needs of graduates who were not enrolled in agricultural and natural resources communications to those who received educational training in the course.

4. Due to the benefits of agricultural and natural resources communications, the course should be evaluated for consideration as a required course in the curriculum for students of the Davis College of Agriculture, Forestry and Consumer Sciences.

5. Additional research should be conducted to investigate the effectiveness of teaching strategies used in agricultural and natural resources communications and their impact on student learning and retention.

6. Consideration should be given to adding an additional communications course to the curriculum at West Virginia University Davis College of Agriculture, Forestry and Consumer Sciences to include the additional communications skills needed during initial employment and to broaden the educational availability of communication principles to students. 


\section{REFERENCES}

Act of 1887 Establishing Agricultural Experiment Stations, para. 1. (n.d.) Retrieved March 24, 2004, http://www.oardc.ohio-state.edu/www/hatch.html.

Akers, C.W. (2000). High school agricultural communications competencies: A national Delphi study. Unpublished doctoral dissertation, Texas Tech University, Lubbock, TX.

Ary, D., Jacobs, L., \& Razavieh, A. (1990). Introduction to research in education. Orlando, FL, Harcourt Brace.

Bailey-Evans, F. (1994). Enhancing the agricultural communications curriculum: A national Delphi study. Unpublished master’s thesis, Texas Tech University, Lubbock, TX.

Buck, C. \& Barrick, R. (1995). Characteristics, educational preparation, and membership in professional organizations of agricultural communicators. (Report OSU-82). Columbus, OH: Department of Agricultural Education.

Case, L., \& Whitaker, K. (1998). What are the goals and purposes of agricultural education?. The Agricultural Education Magazine, 71(3), 6-8.

Coulter, K., Stanton, M., and Goecker, A. (1990). Employment opportunities for college graduates in the food and agricultural sciences. Washington, D.C.: Higher Education Programs, U.S. Dept. of Agriculture.

Dillman, R. M. (1989). Designing and improving courses and curricula in higher education. San Francisco: Jossey-Bass. 
Evans, J. (1969). Toward an academic base for agricultural communications. UrbanaCampaign, IL: University of Illinois-Department of Agricultural Communications report.

Evans, J. (1975). In a fledging discipline. Urbana-Campaign, IL: University of IllinoisCollege of Agriculture Publication 36, 11-23.

Evans, J., \& Bolick, J. (1982). Today's curricula in agricultural communications. ACE Quarterly.

Finch, C., \& Crunkilton, J. (1989). Curriculum development in vocational and technical education: Planning, content and implementation (3rd ed.). Needham Heights, MA: Allyn and Bacon, Inc.

Flatt, C., (1991). Agricultural Communications Graduates' Perception of Curriculum, Preparations and Degree Title. Unpublished masters thesis, Washington State University, Pullman, WA.

Irani, T. and Scherler, C. (2002). Job satisfaction as an outcome measure of the effectiveness of an agricultural communications academic program. Journal of Agricultural Education, 43(3), 12-23.

Hasenauer, J., (2001). Academy shows ins, outs of ag [Electronic version]. North Platte Telegraph, 1-2.

Katsman, L., \& Booker, S. (1998). Writing across the disciplines in agriculture. Language and Learning Across the Disciplines, 2(3), 36-43.

Lockaby, J. \& Vernon, S. (1998). Agricultural communication: what is its connection to agricultural education. The Agricultural Education Magazine, 71(3), 16-18. 
Nash, V. (1928). What is taught in schools of journalism U. of Missouri Bulletin, 29(45), Journalism Series.

National Council for Agricultural Education. (1999). Reinventing Agricultural Education for the Year 2020: A new era in agriculture [Brochure]. Alexandria, VA: Author.

Osmond, J., \& Hoover, T. (1995). Follow-up study of graduates from the College of Agriculture, University of Florida [Electronic version]. Journal of Education and Extension, (2)2, 44-48.

Paulson, C. \& Metzger, M. (1990). Desktop publishing trends within the livestock publications council: Implications for agricultural communications curriculum. Paper presented at International Meeting for the Agricultural Communicators in Education-Research Special Interest Group, St. Paul, MN.

Reisner, A. (1990). An overview of agricultural communications programs and curricula. Journal of Applied Communications, 74(1), 8-25.

Robinson, J., Shaver, P., \& Wrightsman, L. (1991). Criteria for scale selection and evaluation. In J. Robinson, P. Shaver \& L. Wrightsman (Eds.). Measures of personality and social psychological attitudes, New York: Academic Press, 1-16.

Samovar, L. and Mills, J. (1995). Oral Communications: Speaking Across Cultures. Dubuque, IA: Wm.C.Brown Communications, Inc.

Specker, K., (1997). Opinions of instructors, practitioners, and alumni concerning curricular requirements of agricultural communications students at the University of Florida. Unpublished master's thesis, University of Florida, Gainesville, FL. 
Specker, K. \& Rudd, R. (1998). Opinions of practitioners concerning curricular requirements of agricultural communications students at the University of Florida. Journal of Applied Communications, 88(1), 31-42.

Terry, J., \& Bailey-Evans, F. (1995). Competencies needed for graduates of agricultural communications programs. Proceedings of the $44^{\text {th }}$ Annual Southern Agricultural Education Research Meeting, Wilmington, NC, 44, 26-37.

Terry, R., Vaughn, P., Vernon, J., Lockaby, J., Bailey-Evans, F., \& Rehrman, M. (1994). Enhancing the agricultural communications curriculum: A vision for the future. Lubbock, TX. Texas Tech University Press.

West Virginia University. (2003). West Virginia University Undergraduate Catalog 2003-2005. West Virginia University, Purinton House: WV, 1(2) 285. 
APPENDICES 
APPENDIX A

Cover letter to Research Population 


\section{West VirginiaUniversity}

Davis College of Agriculture, Forestry and Consumer Sciences

May 7, 2004

$<$ Name $>$

$<$ Add $>$

$<$ City $><$ State $><$ Zip $>$

Dear $<$ NAME $>$

I am conducting a research study to determine the communication skills needed during initial employment by graduates of the West Virginia University Davis College of Agriculture, Forestry and Consumer Science. Specifically, I am gathering information from graduates who completed Agriculture Communications 421. The results of the study will be used to prepare a thesis to partially fulfill the requirements for a Master of Science Degree in Agricultural Education.

The enclosed questionnaire includes questions on communication skills used in your initial employment, how well you learned the skills in AgEE 421, personal communication skills, and basic demographics. Please read the instructions carefully for each section and respond accordingly. Although your participation is voluntary, I am asking you to please take a few minutes of your time to fill out the form. You may skip any question you are not comfortable answering. Please be assured that all information will be held as confidential as possible. You will notice a code number at the bottom of the left-hand column of the questionnaire. This code will be used to identify nonrespondents for follow-up and will be destroyed before the data are analyzed.

Enclosed with the questionnaire is a self-addressed stamped envelope for your convenience. If we could please return the completion questionnaire by May 26, 2004, I will be greatly appreciative.

Thank you for your cooperation.

Sincerely,

Jessica R. Rollins

Teaching Assistant

Graduate Student
Stacy A. Gartin

Professor \& Chair 


\section{APPENDIX B}

Survey Instrument 


\section{Communication Skills Used During Initial Employment as Perceived by Graduates of the Davis College of Agriculture, Forestry, and Consumer Sciences}

To the best of your knowledge or recollection, please complete this survey following the directions given for each question.

\section{Part A: Communication Skill Use}

Instructions: In this section, please use the scale 5=Always, 4=Often, 3=Occasionally, 2=Rarely and $1=$ Never to indicate the frequency you use the listed items.

Please use the scale $4=$ Very Adequate, $3=$ Somewhat Adequate, $2=$ Adequate, and 1=Not Adequate to indicate the adequacy of the skills taught during your enrollment in the course.

Skill Areas Used

During Initial Employment

1. Communicated with small groups

2. Communicated interpersonally

3. Communicated via telephone

4. Wrote résumés using AgEE Communication format

5. Wrote cover letters using AgEE Communication format

6. Wrote follow-up letters using AgEE Communication format

7. Wrote acceptance letters using AgEE Communication format

8. Wrote resignation letters using AgEE Communication format

9. Wrote speeches inclusive of introduction, body and conclusion

10. Used the communication strategy plan

11. Presented to groups of 5-20 people

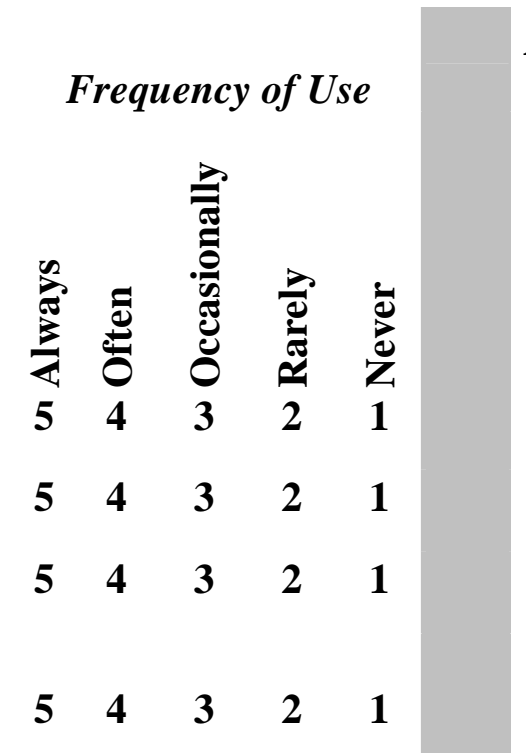

Adequacy of Skills Taught

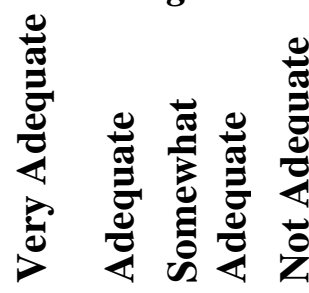

$\begin{array}{llll}4 & 3 & 2 & 1\end{array}$

$\begin{array}{llll}4 & 3 & 2 & 1\end{array}$

$\begin{array}{llll}4 & 3 & 2 & 1\end{array}$

$\begin{array}{llll}4 & 3 & 2 & 1\end{array}$

$\begin{array}{llll}4 & 3 & 2 & 1\end{array}$

$\begin{array}{lllll}5 & 4 & 3 & 2 & 1\end{array}$

$\begin{array}{lllll}5 & 4 & 3 & 2 & 1\end{array}$

$\begin{array}{llll}4 & 3 & 2 & 1\end{array}$

$\begin{array}{lllll}5 & 4 & 3 & 2 & 1\end{array}$

$\begin{array}{llll}4 & 3 & 2 & 1\end{array}$

$\begin{array}{lllll}5 & 4 & 3 & 2 & 1\end{array}$

$\begin{array}{llll}4 & 3 & 2 & 1\end{array}$

$\begin{array}{lllll}5 & 4 & 3 & 2 & 1\end{array}$

$\begin{array}{llll}4 & 3 & 2 & 1\end{array}$

$\begin{array}{llll}4 & 3 & 2 & 1\end{array}$

$\begin{array}{llll}4 & 3 & 2 & 1\end{array}$ 
Skill Areas Used

During Initial Employment
Frequency of Use

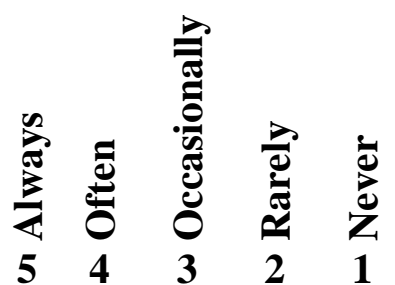

12. Presented to groups of 21-40 people

13. Presented to groups of 41 or more people

14. Spoke to a group for 3-5 minutes

15. Spoke to a group for 8-10 minutes

16. Spoke to a group for 20 minutes or more

17. Introduced a guest speaker

18. Gave/accepted an award

19. Negotiated sales

20. Used audiovisual/media equipment

21. Used a digital camera

22. Used a $35 \mathrm{~mm}$ camera

23. Used transparencies while presenting

24. Used PowerPoint while presenting

25. Used tables/graphs while presenting

26. Acted as an interviewer

27. Wrote/responded to emails

28. Conducted demonstrations

29. Applied knowledge of listening

30. Applied knowledge of verbal communication

31. Applied knowledge of nonverbal communication $\begin{array}{lllll}5 & 4 & 3 & 2 & 1\end{array}$

$\begin{array}{lllll}5 & 4 & 3 & 2 & 1\end{array}$

$\begin{array}{lllll}5 & 4 & 3 & 2 & 1\end{array}$

$\begin{array}{lllll}5 & 4 & 3 & 2 & 1\end{array}$

$\begin{array}{lllll}5 & 4 & 3 & 2 & 1\end{array}$

$\begin{array}{lllll}5 & 4 & 3 & 2 & 1\end{array}$

$\begin{array}{lllll}5 & 4 & 3 & 2 & 1\end{array}$

$\begin{array}{lllll}5 & 4 & 3 & 2 & 1\end{array}$

$\begin{array}{lllll}5 & 4 & 3 & 2 & 1\end{array}$

$\begin{array}{lllll}5 & 4 & 3 & 2 & 1\end{array}$

$\begin{array}{lllll}5 & 4 & 3 & 2 & 1\end{array}$

$\begin{array}{lllll}5 & 4 & 3 & 2 & 1\end{array}$

$\begin{array}{lllll}5 & 4 & 3 & 2 & 1\end{array}$

$\begin{array}{lllll}5 & 4 & 3 & 2 & 1\end{array}$

$\begin{array}{lllll}5 & 4 & 3 & 2 & 1\end{array}$

$\begin{array}{lllll}5 & 4 & 3 & 2 & 1\end{array}$

$\begin{array}{lllll}5 & 4 & 3 & 2 & 1\end{array}$

$\begin{array}{lllll}5 & 4 & 3 & 2 & 1\end{array}$ $\begin{array}{lllll}5 & 4 & 3 & 2 & 1\end{array}$
Adequacy of Skills

Taught

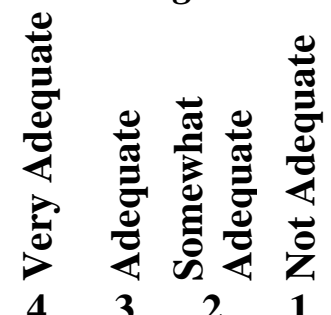

$\begin{array}{llll}4 & 3 & 2 & 1\end{array}$

$\begin{array}{llll}4 & 3 & 2 & 1\end{array}$

$\begin{array}{llll}4 & 3 & 2 & 1\end{array}$

$\begin{array}{llll}4 & 3 & 2 & 1\end{array}$

$\begin{array}{llll}4 & 3 & 2 & 1\end{array}$

$\begin{array}{llll}4 & 3 & 2 & 1\end{array}$

$\begin{array}{llll}4 & 3 & 2 & 1\end{array}$

$\begin{array}{llll}4 & 3 & 2 & 1\end{array}$

$\begin{array}{llll}4 & 3 & 2 & 1\end{array}$

$\begin{array}{llll}4 & 3 & 2 & 1\end{array}$

$\begin{array}{llll}4 & 3 & 2 & 1\end{array}$

$\begin{array}{llll}4 & 3 & 2 & 1\end{array}$

$\begin{array}{llll}4 & 3 & 2 & 1\end{array}$

$\begin{array}{llll}4 & 3 & 2 & 1\end{array}$

$\begin{array}{llll}4 & 3 & 2 & 1\end{array}$

$\begin{array}{llll}4 & 3 & 2 & 1\end{array}$

$\begin{array}{llll}4 & 3 & 2 & 1\end{array}$

$\begin{array}{llll}4 & 3 & 2 & 1\end{array}$

$\begin{array}{llll}4 & 3 & 2 & 1\end{array}$

$\begin{array}{llll}4 & 3 & 2 & 1\end{array}$ 


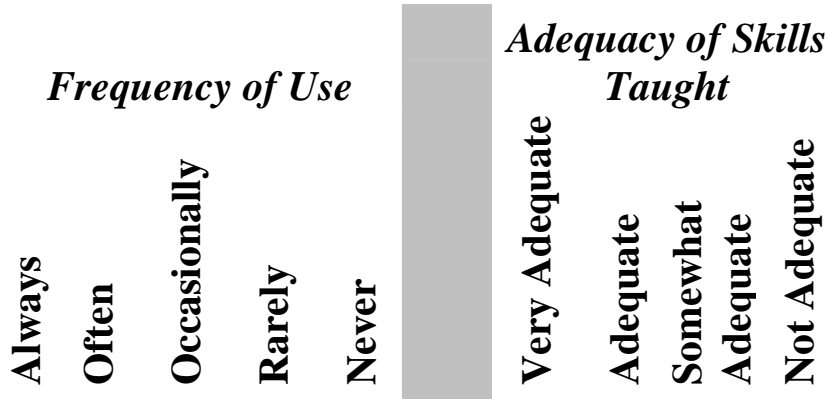

32. General knowledge of communication benefited me during initial employment

33. AgEE Communications provided beneficial knowledge which I actively applied during my initial employment

\section{Part B: Personal Communication}

Instructions: In this section, please answer the following questions with your personal experiences during your initial employment following graduation.

34. What communications skills did you practice regularly in your initial employment that were not taught in the Agricultural Communications course?

35. Which of the skills listed in question 34 should be included in the Agricultural communications course?

\section{Please feel free to write any additional comments on the back of this page}

\section{$\underline{\text { Part C: Demographic Information }}$}

Instructions: Please respond to each question. 
36. Gender

a. Male

b. Female

37. What group best describes your age? (Check one)

a. 20 to 24 years of age

b. 25 to 29 years of age

c. 30 to 34 years of age

d. 35 to 39 years of age

e. 40 to 44 years of age

f. 45 to 49 years of age

g. 50 years of age or older

38. Were you an undergraduate or graduate student when you were enrolled in the Agricultural Communications course?

a. Undergraduate student

b. Graduate student

39. What is the highest degree you have received?

a. Associate's Degree

b. Bachelor's Degree

c. Master's Degree

d. Doctorial Degree

e. Other (specify)

40. What was your major when you were enrolled in the Agricultural Communications course?

a. Agricultural \& Environmental Education

b. Agricultural Resource Economics

c. Animal and Food Science

d. Environmental Protection

e. Forest Resources Management

f. Pre-Veterinary/Pre-Medicine 
g. Wood Industries

h. Recreation, Parks and Tourism Management

i. Horticulture

j. Wildlife and Fisheries Management

k. Agronomy

l. Landscape Architecture

m. Other

41. What was your initial title \&/or position?

42. What types of activities/responsibilities were included in your initial employment?

43. Was your initial employment part or full time?

a. Part-time

b. Full-time

44. What state were you initially employed?

45. Have you received additional formal training \&/or education in communications?

a. Yes

b. No

If so, please list details about the communication skills gained from your additional training. 
APPENDIX C

Follow-up Cover Letter 


\section{WestVirginiaUniversity}

\section{Davis College of Agriculture, Forestry and Consumer Sciences}

June 11, 2004

$<$ Name $>$

$<$ Add $>$

$<$ City $><$ State $><$ Zip $>$

Dear $<$ NAME $>$

We recently mailed to you a survey concerning a thesis study we are conducting to determine the communication skills needed during initial employment by graduates of the West Virginia University Davis College of Agriculture, Forestry and Consumer Science.

As of yet, we have not received your response. If you have responded let us thank you in advance. If not, please take a few minutes to fill out the enclosed form. Your participation is voluntary, but is also vital to the results of this research effort.

Enclosed with the questionnaire is a self-addressed, stamped envelope for your convenience. If we might have your responses by June 28, 2004, we would be most appreciative.

Thank you in advance for your cooperation.

Sincerely,

Jessica R. Rollins

Teaching Assistant

Graduate Student
Stacy A. Gartin

Professor \& Chair 


\section{APPENDIX D}

Second Follow-Up/Late Respondent Letter 


\section{West VirginiaUniversity}

\section{Davis College of Agriculture, Forestry and Consumer Sciences}

August 4, 2004

$<$ Name $>$

$<$ Add $>$

$<$ City $><$ State $><$ Zip $>$

Dear $<$ NAME $>$

We recently mailed to you a survey concerning a thesis study we are conducting to determine the communication skills needed during initial employment by graduates of the West Virginia University Davis College of Agriculture, Forestry and Consumer Science who completed Agriculture Communications 421. The results of the study will be used to prepare a thesis to partially fulfill the requirements for a Master of Science Degree in Agricultural Education.

The enclosed questionnaire includes questions on communication skills used in your initial employment, how well you learned the skills in AgEE 421, and basic demographics. Please read the instructions carefully for each section and respond accordingly. Although your participation is voluntary, I am asking you to please take a few minutes of your time to fill out the form. You may skip any question you are not comfortable answering. Please be assured that all information will be held as confidential as possible. You will notice a code number at the bottom of the left-hand column of the questionnaire. This code will be used to identify non-respondents for follow-up and will be destroyed before the data are analyzed.

As of yet, we have not received your response. If you have responded, we thank you in advance. If not, please take a few minutes to fill out the enclosed form. Your participation is voluntary, but is also vital to the results of this research effort. Dr. Gartin would like for you to respond to this mailing, as it is our third effort to collect data from you.

Enclosed with the questionnaire is a self-addressed, stamped envelope for your convenience. If we might have your responses by August 18, 2004 we would be most appreciative. Thank you in advance for your cooperation.

Sincerely,

Jessica R. Rollins

Teaching Assistant

Graduate Student
Stacy A. Gartin

Professor \& Chair 
VITA

\section{Jessica R. Rollins}

April 2002-May 2003

May 2003

August 2002-May 2004

August 2003- May 2004

December 2004
Undergraduate Research Analyst Animal \& Veterinary Sciences Supervisor: Dr. Gene Felton West Virginia University Morgantown, WV

Bachelor of Science Animal and Veterinary Science West Virginia University Morgantown, WV

Graduate Teaching Assistant Agricultural \& Environmental Education Supervisor: Dr. Stacy A. Gartin West Virginia University Morgantown, WV

Graduate Research Assistant WVU Extension Service Supervisor: Dr. Ed Rayburn West Virginia University Morgantown, WV

Master of Science Agricultural \& Environmental Education West Virginia University

Morgantown, WV 